\title{
Recenzja
}

\section{Joanna Juchniewicz, Absolutorium jako realizacja funkcji kontrolnej Sejmu, Wydawnictwo Uniwersytetu Warmińsko-Mazurskiego w Olsztynie, Olsztyn 2010, ss. 246}

Monografia autorstwa doktor Joanny Juchniewicz Absolutorium jako realizacja funkcji kontrolnej Sejmu stanowi wynik kilkuletnich badań naukowych autorki, jest pogłębioną i zmienioną wersją rozprawy doktorskiej obronionej w czerwcu 2007 r. Praca ukazała się nakładem Wydawnictwa Uniwersytetu Warmińsko - Mazurskiego w Olsztynie. Porusza ona wszechstronnie problematykę absolutorium - tj. aktu prawnego (uchwały) Sejmu uznającego prawidłowość działalności finansowej Rady Ministrów (wykonania ustawy budżetowej) w okresie roku budżetowego. W pracy autorka przedstawiła szerokie ujęcie historyczne instytucji skwitowania działalności finansowej organów wykonawczych; procedurę przygotowywania i uchwalania ustawy budżetowej oraz procedurę podejmowania uchwały w przedmiocie absolutorium i jej konsekwencje. W tym miejscu należy podkreślić trafność wyboru tematyki badanych zagadnień. W Polsce po roku 90 i wcześniej opublikowano wiele prac dotyczących problematyki absolutorium. Jednajże dopiero opracowanie dr J. Juchniewicz ma charakter kompleksowy i całościowo obejmuje zagadnienia związane z procedurą budżetową wraz z sejmowym skwitowaniem realizacji budżetu tj. udzieleniem rządowi absolutorium.

Celem pracy jest przedstawienie funkcjonowania absolutorium, jego skutków i realnego wpływu na działalność Rady Ministrów w zakresie realizowanej przez ten organ polityki finansowej. Autorka dokonuje analizy powyższych zagadnień zarówno w aspekcie normatywnych wzorców jak również funkcjonowania instytucji absolutorium w praktyce. Stawia ona i analizuje niezwykle doniosłe pytanie „(...) czy absolutorium, stanowiące konstytucyjną instytucję kontroli, pozwala Sejmowi w sposób rzeczywisty kontrolować działalność Rady Ministrów w aspekcie wykonania ustawy budżetowej" (s. 10). Teza ta w pracy została zweryfikowana negatywnie. Autorka prowadząc badania posługiwała się przede wszystkim metodą do- 
gmatyczno-prawną. Posiłkowo wykorzystała metody historyczno prawną i prawno porównawczą. Badania autorki skupiały się przede wszystkim na analizie przepisów prawa oraz praktyki sejmowej. Praca koncentruje się na aspekcie prawniczym instytucji absolutorium i tylko w niewielkim zakresie odnosi się do perspektywy politologicznej i socjologicznej tej instytucji.

Praca zasadniczo składa się z dwóch części: pierwszej historycznej, w której autorka opisuje instytucję skwitowaniu budżetu w okresie począwszy od połowy XVI w. aż do roku 1997, tj. do czasu uchwalenia obecnie obowiązującej ustawy zasadniczej. W drugiej części opracowania naukowego przedstawiono obecnie obowiązujące: podstawy prawne funkcjonowania instytucji absolutorium, procedurę budżetową, procedurę podejmowania uchwały w przedmiocie absolutorium, praktykę parlamentarną oraz samą uchwałę i jej skutki prawne.

Pierwsze trzy rozdziały mają charakter historyczny (s. 17 - 95). Przedstawiono w nich genezę i rozwój instytucji absolutorium. Znamienny jest fakt, iż autorka zdecydowała się przeznaczyć prawie połowę opracowania na rozważania dotyczące historycznych aspektów omawianego zagadnienia. We wstępie pracy uzasadniła ona przyjętą przez siebie koncepcję badawczą wskazując, że „dopiero uwzględnienie ewolucji instytucji, daje możliwość całościowego omówienia wspomnianych zagadnień" (s. 10). Autorka wskazuje, iż instytucje historyczne mają bardzo ważne znaczenie dla rozumienia i postrzegania obecnych rozwiązań ustrojowych. To stwierdzenie, w mojej ocenie całkowicie trafne, uzasadnia przedstawienie w pracy rozbudowanej genezy absolutorium. Niewątpliwie bowiem, rozwiązania zastosowane we wcześniejszych okresach istotnie oddziałują na kształt późniejszych koncepcji i umożliwiają pełniejsze zrozumienie ich kształtu i znaczenia, stanowią ponadto swoisty fundament będący oparciem dla współczesnych koncepcji. Jednakże w samej pracy (w dalszej jej części) zabrakło mi bezpośrednich odniesień historycznych do kształtu obecnych rozwiązań i szerszego potraktowania wykładni historycznej jako instrumentu dekodowania współcześnie obowiązujących regulacji prawnych (wyjątek w tym przedmiocie stanowią uwagi na s. 112, 203, 212, 221). Jednakże sama doniosłość podjętych badań historycznych i ciekawość zastosowanych rozwiązań już stanowi wystarczające uzasadnienie dla tej części pracy. Przedstawione przez autorkę szerokie tło historyczne kwitowania wykonania budżetu umożliwia mocne osadzenie tej instytucji w kontekście systemowym, aksjologicznym i teleologicznym. 
W części historycznej autorka nie odnosi się do funkcji kontrolnej Sejmu. Związane jest to $\mathrm{z}$ faktem, iż skwitowanie finansów nie zawsze dokonywane było przez Sejm i nie zawsze dotyczyło działalności Rady Ministrów.

Druga cześć pracy (rozdziały IV-VII) koncentruje się na współcześnie obowiązujących rozwiązaniach prawnych związanych z instytucją absolutorium i szeroko rozumianą procedurą budżetową. W czwartym rozdziale, zatytułowanym Konstytucyjno-ustrojowe podstawy instytucji absolutorium, przedstawiono podstawowe pojęcia wykorzystane w pracy. W pewnej mierze jest to zasadnicza cześć dysertacji, mająca szczególnie doniosłe znaczenie metodologiczne. Autorka definiuje w niej podstawowe terminy mające istotne znaczenie dla dalszych rozważań naukowych tj. kontrola, funkcja kontrolna, absolutorium. W tym rozdziale autorka odwołuje się nie tylko do teorii i definicji ustalonych na gruncie prawa konstytucyjnego, ale również odnosi się do terminów ukształtowanych na gruncie innych gałęzi prawa w tym przede wszystkim prawa administracyjnego oraz innych dziedzin i nauk tj. filozofia prawa, politologia, socjologia. Dzięki temu ustalone przez autorkę definicje cechują się dużą uniwersalnością i poprawnością, choć jak sama słusznie zauważa terminy te są na tyle wieloznacznie i mogą być postrzeganie na tak wiele sposobów, że nie sposób stworzyć jednoznacznej, niewątpliwej i całkowicie uniwersalnej definicji. Należy zgodzić się z przedstawionymi w tej czyści pracy interesującymi rozważaniami i uwagami autorki dotyczącymi rozróżnienia pojęcia i skutków kontroli w ujęciu administracyjno-prawnymi i w ujęciu konstytucyjno-prawnym (parlamentarnym) (s. 97 i 104). Nadto w tym rozdziale pokrótce przedstawiono normatywne podstawy: procedury budżetowej, budżetu, absolutorium, kontroli sejmowej, które zawarte są w Konstytucji RP oraz innych aktach normatywnych (s. 102). Rozdział ten ma również szczególne znaczenie dla rozwinięcia tematu całości pracy, bowiem właśnie w nim przedstawiona została funkcja kontrolna Sejmu i jej związek z instytucją absolutorium. Autorka definiując powyższą funkcję koncentruje się przede wszystkim na relacjach Sejm-Rada Ministrów, pomija natomiast realizację tej funkcji w innych płaszczyznach działalności izby poselskiej, w szczególności w zakresie kontroli działalności pozostałych organów władzy. Równocześnie praca nie koncentruje się tylko wąsko rozumianej sejmowej kontroli działalności Rady Ministrów związanej z budżetem i jego wykonaniem. Porusza ona również inne aspekty od- 
powiedzialności rządu przed Sejmem za działalność nie tylko bezpośrednio związaną z finansami publicznymi.

Rozdziały V i VI mają charakter proceduralny. Autorka koncentruje się $\mathrm{w}$ nich przede wszystkim na postępowaniach wewnątrz parlamentarnych związanych z przygotowaniem, uchwaleniem i wykonaniem ustawy budżetowej oraz przygotowaniem i pojęciem uchwały w przedmiocie absolutorium.

$\mathrm{W}$ rozdziale $\mathrm{V}$ przedstawiono przede wszystkim odrębności proceduralne związane $\mathrm{z}$ przygotowaniem, wniesieniem projektu oraz uchwaleniem ustawy budżetowej w stosunku do trybu postępowania ze zwykłymi ustawami. Ponadto, w tej części pracy omówiony został problem dopuszczalności uchwalania ustawy budżetowej w trybie pilnym. Autorka w konkluzji wskazała, iż zastosowanie art. 123 Konstytucji jest niedopuszczalne w stosunku do projektu ustawy budżetowej. Istnieje natomiast możliwość wykorzystania tzw. szybkiej ścieżki legislacyjnej w stosunku do ustaw zmieniających ustawę budżetową (por. s. 141). Stanowisko autorki jest uzasadnione i zasługuje na aprobatę. W rozdziale tym przedstawiona została również rola Prezydenta RP oraz Trybunału Konstytucyjnego w przypadku zaskarżenia ustawy budżetowej do sądu konstytucyjnego. Ostatnia cześć tego rozdziału zawiera rozważania dotyczące skutków nieuchwalenia ustawy budżetowej oraz jej wykonania. W części poświęconej ustawie budżetowej zabrakło mi teoretycznych rozważań dotyczących charakteru prawnego tego szczególnego aktu normatywnego. Ustawa budżetowa jest źródłem prawa i jako taka powinna zawierać normy prawne o charakterze generalnym i abstrakcyjnym. Znamiennym jest, iż większość regulacji tej ustawy tych cech nie posiada. Przykładowo normy ustawy budżetowej nie są powtarzalne. Zachodzi więc pytanie o ich status i znaczenie normatywne. Jeszcze bardziej skomplikowany jest charakter prawny projektu ustawy budżetowej (o prowizorium budżetowym), na podstawie którego Rada Ministrów prowadzi gospodarkę budżetową, jeżeli ustawa ta nie weszła w życie w dniu rozpoczęcia roku budżetowego (por. art. 219 ust. 4 Konstytucji RP z 1997 r.). Nasuwają się tutaj istotne pytania, czy tego typu wykonywany projekt nieuchwalonej ustawy budżetowej jest aktem normatywnym, czy stanowi źródło prawa i jaka jest jego pozycja w systemie prawnym. Autorka wskazała, iż późniejsze uchwalenie ustawy budżetowej „sanuje” wykonywane regulacje projektu (s. 156). Rozumiem przez to, iż uzyskują one w ten sposób przymiot normatywno- 
ści. Jednakże co się z nimi stanie w sytuacji gdy ustawa budżetowa nie zostanie uchwalona? Niestety, nie tylko w omawianym opracowaniu, ale również w nauce prawa brakuje pogłębionej refleksji na ten temat.

Rozdział VI pracy opisuje procedurę podejmowania uchwały w przedmiocie absolutorium. Zawarte w nim przemyślenia i konkluzje dotyczą działalności Sejmu, jego organów oraz NIK. W rozdziale tym zawarto szerokie rozważania dotyczące pozycji ustrojowej Najwyższej Izby Kontroli oraz kryteriów kontroli (s. 170-185). W mojej ocenie nie są one konieczne dla istoty pracy, w szczególności, że autorka wcześniej nie opisuje pozycji ustrojowej organów, których działalność stanowi istotę pracy tj. Sejm i Rada Ministrów.

Ostatni rozdział pracy (Uchwała w przedmiocie absolutorium) stanowi zwieńczenie całości badań. Ta cześć opracowania zawiera liczne uwagi porównawcze do rozwiązań przyjętych w innych państwach oraz analizę i zestawienie wszystkich procedur, uchwał oraz wyników głosowań podjętych w przedmiocie absolutorium przez Sejm po wejściu w życie Konstytucji z 1997 r. W rozdziale tym przedstawiono również skutki polityczne i prawne udzielenia oraz nieudzielenia absolutorium Radzie Ministrów. Joanna Juchniewicz stoi na stanowisku, iż nieudzielenie absolutorium nie powoduje automatycznej dymisji rządu (nawet nie skutkuje obowiązkiem udzielenia wotum nieufności). W tej części pracy autorka przedstawiła i uzasadniła, w mojej ocenie, zasadniczą tezę całości opracowania. Mianowicie, brak jasno określonych skutków prawnych odmowy udzielenia absolutorium bardzo osłabia tę instytucję. Rada Ministrów nie musi się obawiać nieprawidłowego wykonania budżetu. W konsekwencji „absolutorium staje się instytucją «fasadową», mało skuteczną formą kontroli nad działalnością władzy wykonawczej" (s. 226). Jedyny zarzut jaki mogę postawić, to że w mojej ocenie, teza ta jest zbyt słabo wyeksponowana na tle całości pracy. Autorka nadto wskazała, iż podstawową słabością tej instytucji jest fakt, iż najczęściej rządy oceniane są przez parlamenty (koalicje), które wcześniej je powołały. Stanowi to kolejną słabość tej instytucji. Nie ma bowiem możliwości by koalicja parlamentarna nie udzieliła swojemu rządowi absolutorium. Autorka podkreśliła, iż parlamentarzyści przywiązują zbyt małą uwagę do opinii NIK, która jest immanentnym elementem procedury uchwałodawczej związanej z absolutorium. Inną wadą przyjętych rozwiązań jest możliwość udzielania absolutorium za wykonanie budżetu przez rząd, który w momencie podejmowania uchwały już nie istnieje (w konsekwencji skutki absoluto- 
rium będą się odnosić do innego gabinetu). Jako podstawową funkcję instytucji absolutorium autorka wskazała funkcję dydaktyczną, która ma na celu ujawnianie nieprawidłowości w przygotowaniu i wykonaniu budżetu oraz ich uniknięcie w przyszłości.

Podsumowując, należy stwierdzić, iż cała praca stanowi spójny i logiczny wywód dotyczący procedury budżetowej, procedury udzielania absolutorium oraz jego skutków prawnych i pozaprawnych w szczególności politycznych. Praca zawiera ocenę obowiązujących regulacji oraz ukształtowanej na ich podstawie praktyki parlamentarnej. Opatrzona ona została, co prawda rozbudowanym, ale bardzo interesującym wprowadzeniem $\mathrm{z}$ zakresu historii państwa, prawa finansowego i finansów publicznych dotyczących kwitowania budżetu. Ułatwia to zrozumienie całości problematyki i poszczególnych jej zagadnień. Dysertacja napisana została czytelnym, przejrzystym i bardzo przystępnym językiem, co w płaszczyźnie styku takich dziedzin jak prawo i finansowość stanowi jej bardzo duży atut. Doktor Juchniewicz ma cenną i niestety rzadko spotykaną umiejętność pisania w sposób łatwy do odbioru o rzeczach bardzo trudnych. Autorka nie boi się podejmować rozwiązywania i oceny trudnych i niejednoznacznie postrzeganych w doktrynie poglądów i stanowisk. Jasno i w sposób zdecydowany formułuje swoje opinie i poglądy uzasadniając je w wyczerpujący sposób. Nie boi się również polemizować $\mathrm{z}$ uznanymi w dziedzinie autorytetami, co świadczy o samodzielności i odwadze autorki. Przygotowując opracowanie autorka korzystała z bardzo licznych źródeł zarówno polsko jak i obcojęzycznych. Rozważania oparte są na solidnym warsztacie badawczym i prawidłowo zastosowanych metodach. Osadzone są w regulacjach prawnych i przede wszystkim w szeroko rozumianych aktach prawnych parlamentu. Dysertacja niewątpliwie wypełnia lukę w literaturze naukowej, albowiem dotychczasowe prace $\mathrm{z}$ tej dziedziny miały charakter fragmentaryczny i nie traktowały powyższej problematyki w sposób kompleksowy i wyczerpujący. Stanowi ona cenną pozycję, jest godna uwagi i polecenia.

Marcin Dąbrowski (Uniwersytet Warmiński-Mazurski w Olsztynie) 